\title{
Human Resource Development Climate of Selected Commercial Banks in Ethiopia
}

\author{
Worku Mekonnen Tadesse (PHD) \\ Assistant Professor, College of Business and Economics, School of Commerce, Addis Ababa University \\ P. o. box 32410, Addis Ababa, Ethiopia
}

\begin{abstract}
Human resource development climate is a manifestation of overall tone of the organization with respect to employee training, education and development. The objective of the study is to show the status of human resource development climate of selected commercial banks in Ethiopia. An analytical survey research approach was employed to assess the HRD climate of the banks. Employees and managers at head quarters of the selected commercial banks were considered as a sample of the study. Out of 600 employees at head quarters 150 were made to respond to the questionnaire based on the availability sampling techniques. The sampling technique was chosen since the employees are homogenous in terms of awareness regarding the issue of the study. The respondents were requested to fill a questionnaire that was developed by Rao and Abraham (1986). Accordingly, top management commitments, HRD mechanisms and OCTAPAC culture of the Banks were assessed. The findings of the study shows that an average management support, an average HRD mechanisms effort and an average OCTAPAC culture are prevailing within the case banks. Therefore, it can be concluded that the banks are not in a position of exercising conducive HRD climate. In other respect the changes in banking industry is turbulent and which ultimately calls for continuous human resource development. Hence, it was suggested that the managing body of the commercial banks need to support the learning \& potential development of employees by introducing changes in HRD policies and practices which ultimately creates conducive HRD climate.
\end{abstract}

\section{Introduction}

The history of modern banking goes back to the Era of Emperor Menlik in Ethiopia in 1905 with the establishment of Bank of Abyssinia, a private company controlled by the Bank of Egypt. (www.nbe.gov.et ). Since then much progress has not shown in the sector until 1991. It is only after the downfall of the military government in 1991 that the private banks and insurances were flourishing in Ethiopia. As of January, 2016, eighteen commercial banks are operating in the Country. (www.nbe.gov.et). It is obvious fact that the service delivery of bank depends on quality of its work force. The banking sector is so dynamic and experiencing significant changes in its operations and in adopting new technologies. The industry faces intense competition nationally as well as internationally. These challenges lead the industry to compete on competent work forces.

The banking industry in Ethiopia is either government owned or owned by citizens of the country. There is no foreign bank operating in the country so far. The industry plays a significant role in the economy of the country. Banking industry in Ethiopia is in the era of change which is driven by rapid economic development of the country as well as changes resulted in terms of meeting global banks operational requirements. These challenges in other words call for conducive HRD climate of the sector. Abraham (1989) stated that a good HRDC rather than HRD practices by themselves are actually responsible for organizational performance. Many researchers like Ranayee (2000), Chaudhary (2010) and Sharma and Purang (2000) identified that HRD climate affects performance of the organization in a positive manner and boosts employee commitment and their performance. This positive HRD climate makes existing systems more effective and makes the organizations more receptive to the introduction of relevant additional system (Athreya, 1988). A healthy HRD climate certainly bolsters the overall internal environment of the organization, fosters employee commitment, involvement and satisfaction with the job (Mishra. 1999).

Other things being equal, an organization with a better HRDC, competent and committed employees could outperform an organization that scores less on these counts. Though many studies conducted in the area HRDC suggests positive relationship between HRDC and organizational performance as discussed above, there is no systematic studies conducted in the context of Ethiopia so far to the best knowledge of the Researcher. Thus the present study therefore is intended to look at the current status of HRDC of commercial banks in Ethiopia and to add literature in the area of HRD climate.

\section{Statement of the Problem}

Today, the world of work and organization has become increasingly challenging and unstable. This is because of challenges currently facing organizations such as globalization, responsiveness to customers, managing change and new technologies. Technologies and changes are impacting the workplace in a way that requires human resource development to change internal practices and causing a paradigm shift from the old ways of thinking and practices. These activities are reflected in the organizational climate of a given organization. 
In organization's context climate consists of the prevailing conditions that affect the life of employees and the its activities (Smith, 1988). Climate can be explained as relatively persistent set of perceptions held by organization members concerning the characteristics and quality of organizational culture. HRD climate on the other hand is a component of the wider organizational climate. The concept of human resource development climate was developed by Rao and Abraham (1986). HRD climate reveals the perceptions of the employees on the developmental environment of an organization

To cope with dynamic and competitive environment, the commercial banks attempted to change their working systems by implementing up-to-date technologies as well as undergone through change management efforts such as business process reengineering (BPR), implementing new performance management (PM), systems such as balance score card (BSC) and MBO. Though, the banking sector in Ethiopia has been implementing new technology that assists working system, still there are complaints from customers' perspective and the quality of workforce seems not to the required level of global trends in financial sectors based on preliminary investigation of the Researcher. Therefore, it is imperative to conduct the study on the extent of managerial commitment to develop competent and productive workforce, and the broad array of opportunities available for individuals and teams to improve their technical and social skills through training and development to fit this dynamism in the work place.

As the extent of competitiveness on the provision of service largely depends on human resources therefore there is a dire need to examine the HRD climate of the Sector. Thus, this survey will examine the existing HRD climate of financial institutions in Ethiopia based on empirical data and analyze status of the prevailing HRD climate of the case commercial banks and also aimed to fill the research gap in the area of human resource development.

\section{Research Questions}

Based on the problems discussed in the above section, the current study aimed to answer the following basic questions.

Q1: What is the level of management commitment to support HRD climate at the commercial banks in Ethiopia?

Q2. What is the prevailing human resource development culture of the banks?

Q3. To what extent HRD mechanisms employed to develop employees of the banks?

The study targeted to test the following hypothesis:

H1. There is significant relationship between management commitment and HRD Climate.

H2. There is significant relationship between HRD mechanism and HRD climate.

H3. There is significant relationship between management commitment and HRD climate.

\section{Review of Related Literature on Human Development Climate}

In order to reveal the relationship between HRD climate and organizational performance, many researches were conducted in the context of other countries than Ethiopia. The following are among the studies conducted in the area of HRD climate. Using the questionnaire developed by Center for HRD, Xavier Labour Relations Institute (XLRI, India) Rao and Abraham (1986) conducted a survey study by taking 41 organizations in India. Their study revealed that an organization that has better HRD climate and processes is likely to be more effective than an organization that does not have them.

Mohanty and Susmitaparija and Ghansyamsahu (2012) by using the same questionnaire developed by the Center examined the HRD climate of insurance industry in Odisha, India. They found that in the case industry the HRD mechanism was more conducive than the general climate and OCTAPAC culture. To show the impact of HRD climate on job performance, they performed a regression analysis. They concluded that HRD climate was good in the private insurance sector in Odisha and has a positive influence on job performance of the employees. However the impact of HRD climate on job performance can further be strengthened by augmenting the attention of management on employee development and having more effective reward management system and a better psychological climate.

Mittal and Verma (2013) using the same questionnaire measured the general climate, HRD Mechanism and OCTAPACE in SBI bank. They found that employees having different age group, experience and qualification have the same perception towards general climate. However they have shown that the OCTAPACE vary according to the age and experience so the policies need to be customized with respect to it. They uncovered that HRD mechanisms vary according to the experience so the performance appraisal, training and development, reward and feedback, career planning and potential appraisal need to differ with the experience of the employees.

Benjamin and David (2012) conducted a study to measure employees' perception of their affective, normative and continuance commitment in relation to the prevailing developmental climate within the Nigerian banking sector in the context of reforms and change. They considered a sample comprised of 303 employees of selected recapitalized Nigerian commercial banks. The result of their study suggests the existence of positive 
relationship between HRD climate and Organizational Commitment.

Dashi, Mohapatra \& Bhuyan (2013) conducted a survey study on a coal exploring public company in Odisha, to explore the perceptions of employees to figure out the potential HRD climate variables which have relations with job satisfaction of employees. They used the questionnaires used by Rao and Abraham, (1986) and Job Satisfaction (Daftuar,C.N,1997). The findings of their study indicated that there is a significant relationship between HRD Climate and employee job satisfaction.

Benjamin (2012) conducted a study that aimed to examine the relationships among human resource development climate (HRDC), organizational citizenship behavior (OCB) and voluntary turnover intentions (VTI) in the banking sector. The results of their study indicated that the HRDC has a significant relationship with OCB and VTI. However, OCB shows no significant relationship with voluntary turnover intension.

Neeraj Kumari (2013) conducted a study to understand the general HRD climate of an organization named Spanco to show which factor (s) influence the HRD climate of the company. She figured out that HRD climate is favorable in terms of handling employee with care. It paves way for open discussion on problems and solution. Top management understands the importance of human resource and actually translates that realization into day to day practice and HR policies.

Krupa J. Bhatt and Tarjani N. Mehta (2013) conducted a study on HRD climate by considering public sector banks in India. The result of their study shown that the HRD climate in public sector banks is average and the perception of employees regarding the HRD climate do not differs significantly on the basis of gender, qualification and designation but it differs significantly on the basis of age .

\section{Conceptual Frame work}

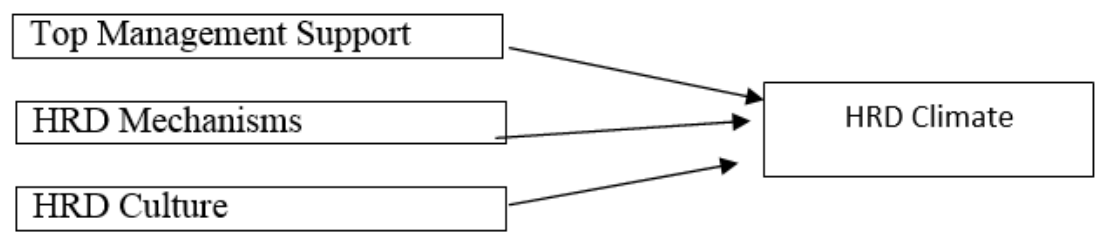

Adopted from Rao and Abraham (1986)

The present study follows the typology of HRDC as developed by Rao and Abraham (1986). They identified three HRDC elements namely: General climate, HRD mechanisms and OCTAPAC culture. General climate provide the views on the top management and line manager's support for HRD. It centers on the attitudes and the behaviors of superiors/supervisors towards employee development. HRD mechanism refers to the implementation of HRD sub-systems such as training, employee appraisal and feedback, career planning, rewards and employee welfare. HRD mechanisms focus on the practicalities of the HRD sub-system and the main issue is how each employee perceives the implementation based on his/her experience within the organization. OCTAPAC culture refers to the degree of openness, confrontation, trust, autonomy, pro-activity, authenticity and collaboration that exist in the organization. The OCTAPAC element examines the psychological state of the organization's development environment-whether it is conducive to creativity and innovation or not.

\section{Methodology}

The study is an explanatory design aimed to examine the HRD climate of the case commercial banks in Ethiopia. The study basically quantitative in its approach. As explained by Miles \& Huberman (1994) in quantitative research, the researcher tends to remain objectively separated from the subject matter. The present survey study obtained information from head office of the selected commercial banks in Ethiopia. Presently 18 commercial banks are operating in Ethiopia. Three banks on convince sampling method were selected. Their head offices are located in Addis Ababa which is the capital city of the Country. Employees working at clerical levels to the top managerial levels are basically the target of the study. Broad strata were formed based on organizational hierarchy namely lower, middle and upper level employees. A total of 170 employees were approached and 150 of them properly filled in the questionnaire. Quota sampling techniques were applied to allocate quota for each categories of employees at head quarter. Finally, each respondent were approached based on the availability sampling techniques as the employees in each category since they are homogenous in terms of knowledge about the subject of the study. A 38-item HRD climate questionnaire developed by the Centre for HRD, Xavier Labor Relations Institute (XLRI) were employed to measures the three components of HRD Climate: the general climate, HRD mechanism and OCTAPAC culture. This survey assumed that using this standard methodology helps to analyze and empirically illustrate the general HRD practice, HRD mechanisms and HRD Policies and practices at the commercial banks in Ethiopia. The mean results of the findings were evaluated based on the average result used by Mohantey and others (2012) shown as follows (1-2.39 poor), (2.4-3.93 average) (3.94-5.0 conducive). This survey assumed that using this standard methodology helps to analyze and empirically illustrate the general HRD practice, HRD mechanisms and HRD mechanisms at the selected commercial banks in Ethiopia. As the study is 
based on perception of the employees all extraneous factors might affect the findings of the study as well the case banks are not fully representative of the banks in Ethiopia hence the findings of the study cannot be generalized for all banks in Ethiopia.

\section{Results and Discussion}

The respondents were drawn from the head offices of selected commercial banks located in Addis Ababa which is the capital city of Ethiopia. The respondents were all employees of the banks considered for the study. Their demographic profile is shown in Table 7.1.

Table 7-1 Demographic Profile of the Respondents

\begin{tabular}{|l|r|r|}
\hline Characteristics & Frequency & \multicolumn{1}{l|}{$\%$} \\
\hline Sex & 100 & 65.4 \\
\hline Male & 50 & 32.7 \\
\hline Female & & \\
\hline Age Category & 25 & 16.3 \\
\hline Under 25 & 97 & 63.4 \\
\hline $25-34$ & 23 & 15.0 \\
\hline $35-44$ & 5 & 3.3 \\
\hline $45-54$ & 2 & 1.3 \\
\hline Above 55 & & \\
\hline Service years in the organization & 55 & 35.9 \\
\hline $0-4$ & 62 & 40.5 \\
\hline $5-9$ & 29 & 19.0 \\
\hline $10-14$ & 5 & 3.3 \\
\hline Over 20 years & & 1.3 \\
\hline Educational qualification & 2 & 7.8 \\
\hline Secondary complete or lower & 12 & 83.0 \\
\hline College Diploma/TVET & 127 & 6.5 \\
\hline BA/BSC/LLB & 10 & - \\
\hline Masters degree & - & \\
\hline PhD & & \\
\hline
\end{tabular}

\section{Source: Questionnaire}

As shown in Table 7.1, the majority of the sampled employees were males $(65.4 \%)$ which are a common fact as observed in many organizations in Ethiopia. For example, the recent CSA (2013) report revealed that out of the total 42,403,879 employed population only 19,517,232 (46.03\%) are females. Age wise the majority of the respondents fall in the age category of 25-34 implying that most of them are youngsters. In terms of the years they served the organization, the majority of them served their respective organization for 5 to 9 years implying that they had adequate exposures to reflect their views as related to the case undertaken for the present study. The level of their educational qualification shows that the majority $(83 \%)$ of them are qualified with first degree and below. This might call HRD interventions to raise their educational level to cope up with the knowledge requirement in the banking sector. The following discussion shows the top management support, HRD mechanisms and OCTAPAC culture that are currently portrayed in the case organizations. Primarily, the general reflection of the respondents in relation to the top management commitment was assessed as shown in Table 7.2 below. 
Table 7.2 Top Management Support for HRD Climate

\begin{tabular}{|c|l|c|c|}
\hline No. & Top Management Support & Mean & SD \\
\hline 1 & $\begin{array}{l}\text { The top management of this organization goes out of its way to make sure that } \\
\text { employees enjoy their work.. }\end{array}$ & 3.2632 & 1.06564 \\
\hline 2 & $\begin{array}{l}\text { The top management believes that human resources are an extremely important } \\
\text { resource and that they have to be treated more humanly. }\end{array}$ & 3.6842 & .89458 \\
\hline 3 & $\begin{array}{l}\text { Development of the subordinates is seen as an important part of their job by the } \\
\text { managers/officers here. }\end{array}$ & 3.4342 & .84313 \\
\hline 4 & The personnel policies in this organization facilitate employee development. & 3.2500 & 1.11135 \\
\hline 5 & $\begin{array}{l}\text { The top management is willing to invest a considerable part of their time and other } \\
\text { resources to ensure the development of employees. }\end{array}$ & 3.4474 & .94756 \\
\hline 6 & $\begin{array}{l}\text { Senior officers/executives in this organization take active interest in their juniors and } \\
\text { help them learn their job. }\end{array}$ & 3.3553 & .96569 \\
\hline 7 & $\begin{array}{l}\text { People lacking competence in doing their jobs are helped to acquire competence } \\
\text { rather than being left unattended. }\end{array}$ & 3.4605 & 1.00911 \\
\hline 8 & $\begin{array}{l}\text { Managers in this organization believe that employee behavior can be changed and } \\
\text { people can be developed at any stage of their life. }\end{array}$ & 3.6579 & .96361 \\
\hline 9 & $\begin{array}{l}\text { Seniors guide their juniors and prepare them for future responsibilities/ roles they } \\
\text { are likely to take up. }\end{array}$ & 3.6842 & .89458 \\
\hline 10 & $\begin{array}{l}\text { The top management of this organization makes efforts to identify and utilize the } \\
\text { potential of the employees. }\end{array}$ & 3.4342 & .84313 \\
\hline & Overall Top Management Support & $\mathbf{3 . 4 0 7 9}$ & $\mathbf{0 . 9 7 8 7}$ \\
\hline
\end{tabular}

\section{Source: Questionnaire}

Table 7.2 portrays the top managers and supervisors effort for the development of their human resources. The items shown in this category targeted to assess the top management commitment, their outlook in terms of the importance they attached for their human resources, the psychological climate and the managers effort to develop their human resources. The group mean average of the items as shown in Table 7.2 was found to be 3.4079 with standard deviation of 0.9787 . The results of each item as shown in Table 7.2 ranges from 3.25 to 3.6579 implying the management involvement and outlook as being evaluated from different direction is consistently at an average level. This result reveals that the general HRD climate of the commercial banks is at an average level. It implied that moderate management support for HRD climate pertains in the case banks implying that the management commitment is at average level. In other instances, the turbulent changes in financial sector calls for high level of commitment and support to cope up with dynamic environments. As stated by Mohantey and others (2012) a congenial HRD climate is essential for sharpening competencies as well as motivating employees to perform exceptionally. 
Table 7.3 Human Resource Development Mechanisms

\begin{tabular}{|c|c|c|c|}
\hline No. & HRD Mechanisms & Mean & SD \\
\hline 1 & $\begin{array}{l}\text { Promotion decisions are based on the suitability of the mechanisms promote rather } \\
\text { than on favoritism. }\end{array}$ & 3.8344 & 1.12208 \\
\hline 2 & $\begin{array}{l}\text { There are mechanisms in this organization to reward any good work done or any } \\
\text { contribution made by employees. }\end{array}$ & 3.8013 & 1.00678 \\
\hline 3 & An employee is appreciated by his/her supervisors when he/she does good work. & 2.9868 & 1.08926 \\
\hline 4 & $\begin{array}{l}\text { Performance appraisal reports in our organization are based on objective assessment } \\
\text { and adequate information, not on any favoritism. }\end{array}$ & 2.7483 & 1.12676 \\
\hline 5 & $\begin{array}{l}\text { Employees are encouraged to experiment with and try out new methods and try out } \\
\text { creative ideas. }\end{array}$ & 2.9139 & 1.07045 \\
\hline 6 & $\begin{array}{l}\text { When any employee makes a mistake his/her supervisors treat it with understanding } \\
\text { and help him/her to learn from such mistakes rather than punishing him/her or } \\
\text { discouraging him/her. }\end{array}$ & 3.3709 & 1.09311 \\
\hline 7 & Weaknesses of employees are communicated to them in a non-threatening way. & 2.9139 & 1.10115 \\
\hline 8 & $\begin{array}{l}\text { When behavior feedback is given to employees they take it seriously and use it for } \\
\text { development. }\end{array}$ & 3.5298 & .90043 \\
\hline 9 & $\begin{array}{l}\text { Employees in this organization take pains to find out their strengths and weaknesses } \\
\text { from their supervising officers } \\
\text { or colleagues. }\end{array}$ & 3.5033 & .88600 \\
\hline 10 & $\begin{array}{l}\text { When employees are sponsored for training, they take it seriously and try to learn } \\
\text { from the programmes they attend. }\end{array}$ & 3.5099 & 97206 \\
\hline 11 & $\begin{array}{l}\text { Employees returning from training programmes are given opportunities to try out } \\
\text { what they have learnt. }\end{array}$ & 3.3642 & .96252 \\
\hline 12 & $\begin{array}{l}\text { Employees are sponsored for training programmes on the basis of genuine training } \\
\text { needs. }\end{array}$ & 3.5695 & 1.17479 \\
\hline 13 & $\begin{array}{l}\text { This organization ensures employee's welfare to such an extent that the employees } \\
\text { can save a lot of their mental energy for work purposes. }\end{array}$ & 2.6453 & 1.04 \\
\hline 14 & Job-rotation in this organization facilitates employee development. & 3.8401 & .9831 \\
\hline & Overall HRDM Group Average & 3.5422 & 1.04 \\
\hline
\end{tabular}

\section{Source: Questionnaire}

As stated by Dash, Mohapatra and Bhuyan (2013) HRD mechanisms are targeting to build three CsCapabilities, Commitment and Culture. Capability building requires developing the knowledge and skills of the person. Capability has to be supported by commitment which comes through desire to excel, positive attitude towards work, co-operation, involvement and concern for one's own self and society. Another important factor of HRD is building culture. Culture is a way of life. It involves creating an awareness of what is ideal and desirable. As shown in Table 4.3 the extent of the implementation of HRD mechanisms, 14 items that are dealing with factors like training and development practices, performance management, career planning and development, reward management etc. were identified from the questionnaire. The group average Mean of the items was found to be 3.5422 with a standard deviation of 1.04. This shows that the HRD mechanisms that the organizations implement in order to create conducive HRD climate is at an average level. It also implied that employees are not much comfortable with the $\mathrm{T}$ and $\mathrm{D}$ effort, performance management, career planning and reward management of the banks. Lowest mean averages rating was obtained for the item that states "this organization ensures employee's welfare to such an extent that the employees can save a lot of their mental energy for work purposes $(\mathrm{M}=2.6453$ with $\mathrm{SD}=1.04)$. The finding of these items reveals that the employees are uncomfortable with the existing welfare mechanisms. The second lowest mean score was obtained for the item that states "performance appraisal reports in our organization are based on objective assessment and adequate information not on any favoritism" (2.7483). This findings also implied that the employees are not happy about the existing performance appraisal practices of the case organizations. In other respect high mean average were obtained as compared to the rest of for the items that state "job-rotation in this organization facilitates employee development. $(\mathrm{M}=3.8401$ and $\mathrm{SD}=.9831)$ and promotion decisions are based on the suitability of the mechanisms promote rather than on favoritism" $(\mathrm{M}=3.8344$ and $\mathrm{SD}=1.12208$ ). The average means of these items show that organization rotate employee on well planned manner targeting employee development as well as employee promotions are based on merit.. The HRD culture that presently persisting in the case organizations is depicted in Table 7.4 below. 
Table 7.4 Human Resource Development Culture

\begin{tabular}{|c|c|c|c|}
\hline No. & OCTAPAC Culture & Mean & $\begin{array}{l}\text { St. } \\
\text { Dev. }\end{array}$ \\
\hline 1 & People trust each other in this organization. & 3.3947 & 1.40556 \\
\hline 2 & $\begin{array}{l}\text { Employees do not feel afraid about their expression of/or Culture discussion of their } \\
\text { feelings with their superiors. }\end{array}$ & 3.5329 & 1.21207 \\
\hline 3 & Employees are not afraid to express or discuss their feelings with their subordinates. & 3.3684 & 1.10198 \\
\hline 4 & $\begin{array}{l}\text { Employees are encouraged to take initiative and do things on their own without } \\
\text { having to wait for instructions from supervisors. }\end{array}$ & 3.2566 & 1.01965 \\
\hline 5 & $\begin{array}{l}\text { Delegation of authority to encourage juniors to develop handling higher } \\
\text { responsibilities is quite common in this organization. }\end{array}$ & 3.4040 & 1.00783 \\
\hline 6 & $\begin{array}{l}\text { When seniors delegate authority to juniors, the juniors use it as an opportunity for } \\
\text { development. }\end{array}$ & 3.2384 & 1.198 \\
\hline 7 & Team spirit is of high order in this organization. & 52 & 15 \\
\hline 8 & $\begin{array}{l}\text { When problems arise people discuss these problems openly and try to solve them } \\
\text { rather than keep accusing each other behind the back. }\end{array}$ & 3.5960 & 1.02097 \\
\hline 9 & Career opportunities are pointed out to juniors by senior officers in the organization. & 3.2781 & 94628 \\
\hline 10 & $\begin{array}{l}\text { ade known to the managerial staff to help them } \\
\text { m for future. }\end{array}$ & 3.64 & .9 \\
\hline 11 & People in this ors & 3.3553 & 1.15322 \\
\hline 12 & $\begin{array}{l}\text { Employees in this organization are very informal and do } \mathrm{n} \\
\text { personal problems with their supervisors. }\end{array}$ & 3.5132 & 1.07953 \\
\hline 13 & $\begin{array}{l}\text { The psychological climate in this organization is very conducive to any employee } \\
\text { interested in developing himself by acquiring new knowledge and skills. }\end{array}$ & 3.2632 & 1.065 \\
\hline 14 & $\begin{array}{l}\text { People in this organization have fixed mental impression/mental reservations about } \\
\text { each other. }\end{array}$ & 0 & 1.11135 \\
\hline & Overall OCTAPAC culture Grou & 3.38 & 0 \\
\hline
\end{tabular}

\section{Source: Questionnaire}

Table 7.4 shows the magnitude of OCTAPAC culture manifested in the commercial banks considered for the study. As stated by Abraham and Rao (1986) OCTAPAC culture refers to the degree of openness, confrontation, trust, autonomy, pro-activity, authenticity and collaboration that exist in the organization. In order to assess the prevailing OCTAPAC culture of the banks, the respondents were asked to rate 14 items from the questionnaire. The group average of the OCTAPAC culture is found to be 3.38 with standard deviation of 1.0974. It means that an average HRD culture persisting in the case organizations. Looking into each of the items, the lowest results were obtained for the items that state "team spirit is of high order in this organization (M=3.0662 with SD of 1.15856), implying that a culture of team spirit is lesser reflected in the case origination. The second lowest Mean average was obtained for the item that states "when seniors delegate authority to juniors, the juniors use it as an opportunity for development (M 3.2384 with SD of 1.19838). This implies that employees do not consider delegation as means of enhancing their capacity. The third lowest rating was given for the item that states "people in this organization have fixed mental impression/mental reservations about each other.( M 3.2500 with standard deviation of 1.11135) implying that employees share ideas among each other at an lesser level as compared to other cultural manifestation depicted.

On the other hand highest mean score were obtained for the items that state "the organization's future plans are made known to the managerial staff to help them develop their juniors and prepare them for future $(\mathrm{M}=3.6490$ with $\mathrm{SD}=.90332)$, and the second highest mean were obtained for the item that states "when problems arise people discuss these problems openly and try to solve them rather than keep accusing each other behind the back" $(\mathrm{M}=3.5960$ with $\mathrm{SD}=1.02097)$ ". The findings of this part suggested that a culture of openness is relatively revealing at a higher degree in the case organizations. The succeeding part of the discussion reveals the findings related to the dimension of OCTAPAC culture i.e openness, confrontation, trust, autonomy, pro-activity, authenticity and collaboration. 
Table 7.5 Openness

\begin{tabular}{|l|l|c|c|}
\hline No. & \multicolumn{1}{|c|}{ Factors } & Mean & SD \\
\hline 1 & $\begin{array}{l}\text { Employees in this organizations are very informal and do not hesitate to discuss } \\
\text { their personal problems with their supervisors. }\end{array}$ & 3.5132 & 1.07953 \\
\hline 2 & $\begin{array}{l}\text { People in this organization have fixed mental impression/mental reservations } \\
\text { about each other }\end{array}$ & 3.2500 & 1.11135 \\
\hline 3 & $\begin{array}{l}\text { Employees do not feel afraid about their expression of/or Culture discussion of } \\
\text { their feelings with their superiors.. }\end{array}$ & 3.5329 & 1.21207 \\
\hline 4 & $\begin{array}{l}\text { Employees are not afraid to express or discuss their feelings with their } \\
\text { subordinates. }\end{array}$ & 3.3684 & 1.10198 \\
\hline & Group Average & $\mathbf{3 . 4 1 6 1 2 5}$ & $\mathbf{1 . 1 2 6 2 3 5}$ \\
\hline
\end{tabular}

Source: Questionnaire

Openness is the expression of thoughts and beliefs of people with one another in a friendly manner. The respondents were requested to rate four items that indicate openness. As shown in Table 7.5 the group mean score relating to the openness culture is 3.416125 with a standard deviation of 1.126235 . The finding of this section suggests the prevailing openness culture of the commercial banks is at an average level. As stated by Rao and Abraham (1986) openness exists when employees feel free to discuss their ideas, activities, and feelings with each other. From the findings of the study it can be inferred that the organizations did not created an atmosphere in which the employees can freely express their ideas and feelings at higher level.

Table 7.6 Confrontation

\begin{tabular}{|l|l|c|c|}
\hline No. & \multicolumn{1}{|c|}{ Factors } & Mean & SD \\
\hline 2 & $\begin{array}{l}\text { Employees in this organizations are very informal and do not hesitate to discuss their } \\
\text { personal problems with their supervisor. }\end{array}$ & 3.5132 & 1.07953 \\
\hline 3 & Employees are not afraid to express or discuss their feelings with their subordinate. & 3.5329 & 1.21207 \\
\hline 4 & $\begin{array}{l}\text { When problem arise people discuss these problems openly and try to solve them } \\
\text { rather than keep accusing each other behind the back. }\end{array}$ & 3.5960 & 1.02097 \\
\hline & Group Average & $\mathbf{3 . 5 4 7 3}$ & $\mathbf{1 . 1 0 4 1 9}$ \\
\hline
\end{tabular}

\section{Source: Questionnaire}

The second part of the OCTAPAC culture assessed was the level of confrontation that persists within the organization. As stated by Rao and Abraham (1986) the better way of handling a problem is to face the problem. By confrontation, problems and issues are brought out into the open with a view to solving them rather than hiding them for fear of hurting or getting hurt. The respondents were asked to rate four items from the questionnaire targeted to figure out the manner of confrontation that persists within the banks. The mean average as shown in Table 7.6 is 3.5473 with a standard deviation of 1.10419 . The findings of this section shows that manner of confronting problem to solve it in an open manner is found to be at a moderate level implying that culture of hiding problems for fear hurting or getting hurt persists within the organization at an average level

\section{Table 7.7 Trust}

\begin{tabular}{|l|l|c|c|}
\hline No. & \multicolumn{1}{|c|}{ Factors } & Mean & SD \\
\hline 1 & People trust each other in this organization & 3.3947 & 1.40556 \\
\hline 2 & People in this organization are helpful to each other. & 3.3553 & 1.15322 \\
\hline 3 & Team spirit is of high order in this organization. & 3.0662 & 1.15856 \\
\hline & \multicolumn{1}{|c}{ Group Average } & 3.2720 & 1.2391 \\
\hline
\end{tabular}

\section{Source: Questionnaire}

Respondents were asked to rate three items that are related to extent of trust culture persist in the organization. The group average of the items was found to be 3.2720 with standard deviation of 1.2391 . The finding of the study reveal that the level of trust culture persisting is moderate. This implied that the banks do not properly create a culture of trust among employees in order to promote team approach for healthier organizations climate. 
Table 7.8 Autonomy

\begin{tabular}{|l|l|c|c|}
\hline No. & \multicolumn{1}{|c|}{ Factors } & Mean & SD \\
\hline 1 & $\begin{array}{l}\text { Employees are encouraged to take initiative and do things on their own without } \\
\text { having to wait for instructions from supervisors. }\end{array}$ & 3.2566 & 1.01965 \\
\hline 2 & $\begin{array}{l}\text { The psychological climate in this organization is very conducive to any employee } \\
\text { interested in developing himself by acquiring new knowledge and skills. }\end{array}$ & 3.2632 & 1.06564 \\
\hline 3 & $\begin{array}{l}\text { Delegation of authority to encourage juniors to develop handling higher } \\
\text { responsibilities is quite common in this organization }\end{array}$ & 3.4040 & 1.00783 \\
\hline 4 & $\begin{array}{l}\text { When seniors delegate authority to juniors, the juniors use it as an opportunity } \\
\text { for development. }\end{array}$ & 3.2384 & 1.19838 \\
\hline & Group Average & $\mathbf{3 . 2 9 0 5 5}$ & $\mathbf{1 . 0 7 2 8 7 5}$ \\
\hline
\end{tabular}

Source: Questionnaire

Respondents were asked to rate four items relating to level of autonomy that persists in the case organizations considered for the study. The group mean of the items was found to be 3.29055 with standard deviation of 1.072875. The finding of this part also reveals that the level of autonomy given for employees is at an average. This shows that employees are limited to applying knowledge they acquired and also magnitude of encouragements for innovations are limited. This further implied that the organizations stifle employees' initiations at an average level.

\section{Table 7.9 Pro-activity}

\begin{tabular}{|l|l|c|c|}
\hline No. & \multicolumn{1}{|c|}{ Factors } & Mean & SD \\
\hline 1 & $\begin{array}{l}\text { The psychological climate in this organization is very conducive to any employee } \\
\text { interested in developing himself by acquiring new knowledge and skills. }\end{array}$ & 3.2632 & 1.06564 \\
\hline 2 & $\begin{array}{l}\text { Employees are encouraged to take initiative and do things on their own without } \\
\text { having to wait for instructions from supervisors }\end{array}$ & 3.2566 & 1.01965 \\
\hline & \multicolumn{1}{|c|}{ Group Average } & 3.2599 & 1.042645 \\
\hline
\end{tabular}

\section{Source: Questionnaire}

According to Rao and Abraham (1986), pro-activity is encouraging employees to take initiative and risk. The group average of the items were found to be 3.2599 with standard deviation of 1.042645 . This shows that the extent of pro-activity given for employees to take initiative and risk are at an average level. In other sense, employees are not properly encouraged to take initiative and limited to wait for instructions.

\section{Table 7.10 Authenticity}

\begin{tabular}{|l|l|c|c|}
\hline No. & \multicolumn{1}{|c|}{ Factors } & Mean & SD \\
\hline 1 & Career opportunities are pointed out to juniors by senior officers in the organization & 3.2781 & .94628 \\
\hline 2 & $\begin{array}{l}\text { The organization's future plans are made known to the managerial staff to help them } \\
\text { develop their juniors and prepare them for future. }\end{array}$ & 3.6490 & .90332 \\
\hline & \multicolumn{1}{|c|}{ Group Average } & $\mathbf{3 . 4 6 3 5 5}$ & $\mathbf{0 . 9 2 4 8}$ \\
\hline
\end{tabular}

\section{Source: Questionnaire}

Authenticity refers to the management efforts to bridge the communication gap that might be created within the organization. The group average of the items were found to be 3.46355 with the standard deviation of 0.9248. It shows that the level of authentic culture that persists within the banks is at moderate level. In other words at an average level employees would not take behavior feed backs seriously implying on average level there is a communication gap among employees.

\begin{tabular}{|l|l|r|r|}
\hline No. & \multicolumn{1}{|c|}{ Factors } & Mean & SD \\
\hline 1 & People in this organization are helpful to each other & 3.3553 & 1.15322 \\
\hline 2 & Team spirit is of high order in this organization & 3.0662 & 1.15856 \\
\hline 3 & $\begin{array}{l}\text { The organization's future plans are made known to the managerial staff to } \\
\text { help them develop their juniors and prepare them for future }\end{array}$ & 3.6490 & .90332 \\
\hline \multicolumn{1}{|c|}{ Group Average } & $\mathbf{3 . 3 5 6 8}$ & $\mathbf{1 . 0 7 1 7}$ \\
\hline
\end{tabular}

\section{Source: Questionnaire}

In collaboration dimension of OCTAPAC culture attempt were made to figure out the extent of employees helpfulness and the magnitude of team work that persists among the workers. The mean average of the items was 3.3568 with standard deviation of 1.0717. The finding of this section shows that the magnitude of cohesiveness culture that persists within the commercial banks considered for the study is not at an average level.

\section{Interrelationship of HRDC Factors}

To further test the hypothesis and show the relationship among the HRD Climate factors correlation matrix of Pearson's Coefficient was performed. The result is shown as follows: 
Table 7.12 Correlation Matrix

\begin{tabular}{|l|l|l|l|l|}
\hline Correlation & TMS & HRDM & OCTAPAC & HDC \\
\hline TMS & 1 & .915 & .934 & .89 \\
\hline HRDM & .915 & 1 & .922 & .92 \\
\hline OCTAPAC & .934 & .922 & 1 & .87 \\
\hline HDC & .89 & .92 & .87 & 1 \\
\hline
\end{tabular}

** Correlation is significant at the 0.01 level (2-tailed)

As shown in the correlation matrix the top management effort has a significance relationship with human resource development mechanism and the OCTAPAC culture. The OCTAPAC culture has a significant relationship with the HRDM. Table 7.12 also shows that each of the HDC factors i.e TMS, HRDM and OCTAPAC have significant relationship to the over all human resource development climate. Hence all alterative hypotheses were proved to be accepted.

Test of differences among the respondents in terms of Gender

In order to test the mean variance difference among the opinion of male and female respondents, one way ANOVA test was performed as shown in Table 7.12 below.

Table 7-13 One way ANOVA

\begin{tabular}{|c|c|c|c|c|c|c|}
\hline Particulars & & Sum of squares & Df & $\begin{array}{l}\text { Mean } \\
\text { squares }\end{array}$ & $\mathbf{F}$ & sig \\
\hline TMS & $\begin{array}{l}\text { between groups } \\
\text { within groups } \\
\text { Total }\end{array}$ & $\begin{array}{l}9.103 \\
87.586 \\
96.690\end{array}$ & $\begin{array}{r}5 \\
110 \\
115\end{array}$ & $\begin{array}{r}1.821 \\
.796\end{array}$ & 2.287 & .051 \\
\hline HRDM & $\begin{array}{l}\text { between groups } \\
\text { within groups } \\
\text { Total }\end{array}$ & $\begin{array}{l}12.576 \\
81.684 \\
94.261\end{array}$ & $\begin{array}{r}5 \\
109 \\
114\end{array}$ & $\begin{array}{r}2.515 \\
.749\end{array}$ & 3.356 & .007 \\
\hline OCTAPAC & $\begin{array}{l}\text { between groups } \\
\text { within groups } \\
\text { Total }\end{array}$ & $\begin{array}{l}12.828 \\
81.433 \\
94.261\end{array}$ & $\begin{array}{r}5 \\
109 \\
114\end{array}$ & $\begin{array}{r}2.566 \\
.747\end{array}$ & 3.434 & .006 \\
\hline
\end{tabular}

The one way ANOVA depicts that calculated F- values for TMS, (2.287>0.051) HRDM (3.356>0.07) and OCTAPAC (3.434>0.006) comes out to be greater than significant levels. The analysis clearly states that Top management support (TMS), Human Resource Development Mechanism (HRDM) and OCTAPAC culture have significant value on human resource development climate. Therefore, the findings of the ANOVA test supports the rejection of the null hypotheses.

\section{Concluding Remarks and suggestions}

The banking industry is at boom stage in the Ethiopian context. It is a recent phenomenon on that 18 commercial banks operating in Ethiopia. The banks are expanding their branches at rapid rate. In other words, the banks are expected to compete internationally as well as nationally. In this regard, their competent weapon is their human resource. Trained and competent human resource can make the organizations profitable as the quality of their service delivery depends on their human resources. To assess the HRD Climate of the commercial banks, the general HRD climate, the OCTAPAC culture, HRD mechanisms were assessed. The study found that the general HRD climate i.e. management support for HRDC and the implementation is at average level. The level of HRD culture i.e. the degree of openness, confrontation, trust, autonomy, pro-activity, authenticity and collaboration is at moderate level. The mechanisms that the organization implement in order to create conducive HRD climate i.e the banks training and development mechanism, reward management, performance management was also found at a moderate level. From the findings of the study it can be concluded that conducive HRD climate did not prevail in banks to the expected level. Therefore it is suggested that the managing body of the commercial banks need to support the learning \& potential development of employees by introducing changes in HRD policies and practices which encourages the employees to contribute their best in all activities and ultimately create conducive HRD climate. 


\section{References}

Akinyemi, Benjamin O. Human Resource Development Climate (HRDC) in the Banking Sector: General and Gender Perceptions. International Journal of Business and Management. Canadian Center of Science and Education, Vol. 7, No. 5.

Armstrong, M. (2007). A Handbook of Employee Reward Management and Practice. London and Philadelphia: Kogan Page Ltd.

Athreya, M. B. (1988). “Integrated HRD System-Intervention Strategies". In: Rao, T. V., K.K. Verma, A.K. Khandelwal and E. Abraham (ed.). Alternative Approaches and Strategy of Human Resources Development. Jaipur: Rawat Publication.

Benjamin, Akinyemi and Iornem, Davi (2012). "Human Resource Development Climate and Employee Commitment in Recapitalized Nigerian Banks. International Journal of Business and Management. Candian Center of Science and Education, Vol. 7, No. 5.

Choudhary, N. (2010)." HRD Climate and job satisfaction: An Empirical Investigation”. International Journal of Computing and Business Research. Vol.2, Issue.2.

Dashi, Srinibash, J. Mohapatra and Lipika Bhuyan (2013). "A Correlation of HRD Climate with Job Satisfaction of Employees: An Empirical Investigation on MCL”. International Business Research. Burla, Sambalput, Odisha Vol. 5, No. 1.

Mishra, M. (1999). Job Satisfaction as a Correlate of HRD Climate (An Empirical Study). Indian Journal of Training and Development. 29 (2): 5.

Mohanty and Susmitaparija and Ghansyamsahu (2012). An Empirical Study on HRD Climate and Its impact on Job performance in Private Companies in Odisha, India. International Journal of Multidisciplinary Research, Vol.2, Issue 5.

Moran, E.T., \& Volkwein, J.F. (1992). The cultural approach to the formation of organizational climate. Australian Journal of Communication. 17, 98-112.

Neeraj, K. (2013). A Study on the OCTAPACE Culture of an Organization. Open Journal of Social Science Australian Journal of Communication. 17, 98-112.

Rainayee, Riyaz (2002)."HRD Climate in Commercial banks: An Empirical study”. The Business Review Vol. 9 No.1 September.

Rao, T.V. \& E. Abraham (1986). "Human Resource Development Climate in Indian Organizations". In: Rao T. V. and D. F. Pereira (ed.). Recent Experiences in Human Resource Development. pp. 70-98. New Delhi: Oxford \& IBH.

Rao, T.V., \& Abraham, E. (1990). The HRD Climate Survey. In J.W. Pfeiffer (Ed.). The 1990 annual Developing Human Resources. San Diego, CA: University Associates.

Schernerhorn John R, Hunt, Richard N. Osborn and Mary Uhl-Bien (2010). Organizational Behavior. USA: John Wiley \& Sons.

Schneider, B. (1990). Organizational climate and culture. San Fransico: Jossey- Bass Publishers.

Sharma and Purang (2000)."Value Institutionalization and HRD Climate: A Case Study of a Navratna Public Sector Organization, Vision". The Journal of Business Perspective, Vol. 4, PP 11-17.

Smith, R.L. (1988). Human Resource Development, An overview, ERIC/CAPS, Michigan: Ann Arbor. www.nbe.gov.et. 